\title{
READING PSALM 78 MULTIDIMENSIONALLY: THE AUTHORIAL DIMENSION ${ }^{1}$
}

\author{
Yeol Kim \& HF van Rooy \\ School for Biblical Studies \\ Northwest University
}

\begin{abstract}
This article is part of an attempt to read Psalm 78 multidimensionally. It is the second in a proposed series of three articles. ${ }^{2}$ The articles deal with the dimension of the author, as part of the multi-dimensional reading. It deals with the heading of the Psalm, ihe redaction history of the Psalm, its dating and historical setting and its canonical shape. The Sitz im Leben of the psalm is the recitation of the psalm in the Jerusalem temple by a (Levitical) priest, when there was an attempt to unite the worship of the North and the South during the divided monarchy (922-587 B.C.). The traditions of wisdom, covenant-Torah, guidance, wilderness, Exodus, and conquest are united in Psalm 78, forming a new welded tradition which stresses the importance of remembrance with regard to the survival of the ancient traditions. Psalm 78 can be seen as an example of God's response to ihe questions and complaints from the adjacent psalms and other psalms in Book III of the Psalter. In this regard, Psalm 78 is not a mere report of Israel's failure, but of the triumph of Yahweh's covenantal faithfulness which creates a new beginning for the people of God.
\end{abstract}

\section{Introduction}

This article is the second in a series of articles on Psalm 78. The different articles are part of an experiment in a multidimensional reading and each of them will deal independently with an aspect of the interpretation of Psalm 78. While the first article (see Kim \& Van Rooy, 2000:285-298) deals with a reading of the textual dimension of Psalm 78, this article will deal with a reading of its authorial dimension.

\section{An Introduction to the reading of the authorial dimension}

Each text of any literature has its origin from somewhere and someone. Likewise, each biblical text has its genesis. With regard to the interpretation of an Old Testament text, its genesis can be investigated by studying the authorial dimension of the text. By nature the study of the authorial dimension is diachronic, but each level can also be described synchronically (cf. Jonker, 1996:405). For the biblical text, especially, the synchronic aspect of the authorial dimension should be regarded as the natural point of departure for the subsequent exegetical process, since the original authors of biblical texts are no longer participants in the process (see Lategan, 1992:153). However, it does not mean ignoring the diachronic aspects of the authors in producing texts, but it rather focuses on the product rather than the process (see Erickson, 1993:31).

For the interaction of the communication process the mutual character of the

1. This article is partly based on Y Kim's MTh dissertation: Reading Psalm 78 multidimensionally. Cf. $\operatorname{Kim}(1999)$.

2. For the first one, cf. Kim \& Van Rooy, 2000. 
synchronic and the diachronic aspects of the authorial dimension can provide the basis for the description of the interactions which take place between the author and the text as well as between the author and the reader (cf. Jonker, 1996:404).

In this study, based on the mutual character of synchronic and diachronic aspects of the authorial dimension, an investigation of the heading of Psalm 78 will be done firstly. Thereafter, an investigation of the tradition history in Psalm 78 and an investigation of the dating and the historical setting (with the Sitz im Leben) will be evaluated. Finally, an analysis of the canonical shape of Psalm 78 will be done under the assumption that the synchronic aspect of the authorial dimension can make provision for the possibility of other texts forming an inter-textual structure of which this text is a part (cf. Jonker, 1998:5). Since this study is an experiment in the notion of a multidimensional reading, each section is introduced by a brief discussion of the methodology of the relevant reading process.

\section{The heading of Psalm 78}

Of the 150 psalms, all but 34 have headings of some sort in the Hebrew text. Some of these headings refer to the literary form of the Psalms and contain various notes on its use mainly in the worship of Israel. Other headings contain reference to historical background and the names of various people who are known from other biblical sources. In the history of psalm studies it was traditionally assumed that the headings contain the names of the authors of the various Psalms (see Tate, 1984:364; also Leupold, 1959:5).

However, a wide consensus has been reached among critical scholars that the headings are secondary additions, which can afFord no reliable information towards establishing the genuine historical settings of those psalms (see Childs, 1979:520). In fact, it seems that most psalm headings were not initially an integral part of the psalms themselves. Most biblical scholars view the headings as a product of Midrashic activity stemming from the age of the scribes (see Solomovic, 1979:350-351). This is verified by the occurrence of different headings among various old manuscripts. Furthermore, some scholars indicate uncertainty over the function of the names found in the psalm headings (see Weiser, 1962:95-98; Kaiser, 1975:350-352; also Schmidt, 1984:301). It is, thus, quite dangerous to rely too much on the headings as keys to the interpretation of the Psalms.

At the same time, however, the psalm headings still can be regarded as the reflection of some earlier exegesis of the Psalms (see Childs, 1971:137). Then they become valuable references to the history of the exegesis of the Psalms. The solution, thus, is to regard the psalm headings as part of an early tradition concerning the authorship and setting of the psalms (cf. Dillard \& Longman, 1994:215). In this regard, even if the psalm headings are later additions by editor(s), they are still very ancient and therefore have a claim to authenticity (see Kidner, 1973:32-33; also Hill \& Walton, 1991:274-275). Therefore, the

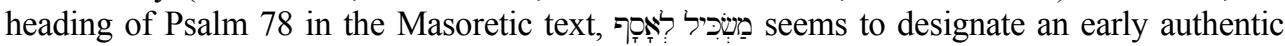
tradition concerning the authorship and setting of the psalm and the literary form of the psalm in question.

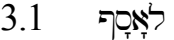

לָָ can be translated as for Asaph, by Asaph (viz. belonging to Asaph as author), to Asaph (perhaps in the sense dedicated to Asaph), wiih reference to Asaph; concerning Asaph, and for the use of Asaph (see Craigie, 1983:33-34). According to Ezra 2:40, Asaph was the ancestor of temple singers; the Chronicler (1 Chronicles 6:39; 15:17; 16:5f; and 2 Chronicles 5:12) makes him one of David's chief musicians. Thus, "Asaph" in the psalm heading may be an abbreviation for the "sons of Asaph," and it may suggest that the 
Asaphite psalms may have been either composed or handed down by this guild of temple singers (see Anderson, 1972:45). Asaphite psalms comprise the group of Psalms 73-83 with the addition of Psalm 50. The collection of Asaphite psalms is one of six basic collections, which constitute the largest part of the Psalter. ${ }^{3}$

Of some interest, also related to the Asaphite psalms, is the fact that the Psalter can be divided into three principal sections based upon the predominant incidence of a particular name of God. The first of these, comprising Psalms 1-41, uses the Tetragrammaton (יהוהים) only 15 times. The second, embracing Psalms 42-89, uses the Tetragrammaton 74 times and Ehohim 207 times. The final division, comprising Psalms 90-150, uses the Tetragrammaton on 339 occasions, whereas Ehohim is found only 7 times. Precisely why the divine name is used in this manner is unknown, but it would seem to be connected with editorial preferences rather than with either historical or theological considerations (Harrison, 1969:987). In this sense, the Asaphite psalms close the so-called Elohistic Psalter.

The Korahite psalms (Psalms 42-49; 84-88) which probably formed the repertoire of Korah's family of Temple singers, can also be classified as part of the so-called Elohistic Psalter. These Korahite psalms "have long been recognized as constituting a relatively homogeneous group" (Buss, 1963:382) related to the Asaphite psalms. These Asaphite and Korahite psalms exhibit the following similar genres: collective lament, Deuteronomic-Levitical psalms of judgement, and law. In addition to these, history occurs among the Asaphite psalms and songs of Zion among the Korahite psalms. Some of them also involve cult personnel and wisdom reflection (Buss, 1963:391-392). This process may indicate that the purpose of the compilation was the production of a collection of hymns specifically designed for the temple worship, at a time when the divine name Yahweh (יהוה) was used only with considerable hesitation (cf. Craigie, 1983:30).

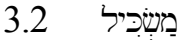

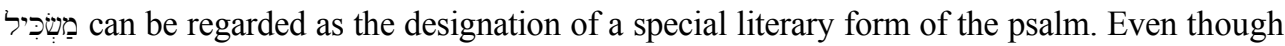
there is no agreement concerning its translation (see Anderson, 1972:47), most of the interpreters assume that the thought of wisdom and teaching impresses itself on Kraus, 1988:25; also Archer, 1994:498). In this regard, it can denote a poem of didactic character, a wisdom song. Among the Asaphite psalms, Psalm 73 is a wisdom song with a strong personal note. Likewise, Psalm 78 begins with the wisdomlike words (see Kim \& Van Rooy 2000:289; also Kim 1999:45-47).

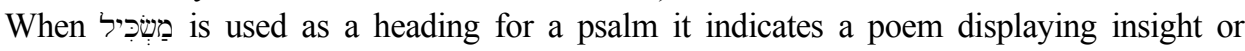
wisdom about life in general or certain events in particular. Within the community such a poem tends to become a didactic statement designed for the instruction of its hearers/ readers. Displaying acute insight into life, it aims at developing an equal insight in the minds of the members of the community (see Harrison, 1969:981). This didactic type of psalm was most probably the product of the so-called חָדָָָז stratum of Israelite society (Carroll, 1971:133).

In the Asaphite psalms historical tradition (Psalm 78) and judgement themes (Psalms $50,75,76,81$ and 82 ) feature in clear connection with a ritual or a holy place. According to Buss (1963:384) judgement songs and historical recapitulation are the work of religious leadership in which a higher level of cultic poetry is represented. The Asaphite psalms reveal

3. For the detailed discussions of six basic collections of the Psalter, see Hill \& Walton, 1991:275; Craigie, 1983:28-29;alsoRendtorfif, 1985:247. 
a closer participation in public events or preaching than do most of the Korahite psalms.

Therefore, the heading of Psalm 78 can be attributed to Asaph or the sons of Asaph, the guild of temple singers, giving to the psalm a didactic character by making use of historical recapitulation. In the temple singing of Israel the singing itself was rather more in the nature of a recitation than of singing tunes in a modern sense (Mowinckel, 1992:83-84). Accordingly Psalm 78 had probably been sung at the Temple service by Asaph or the sons of Asaph in the manner of a recitation of the historical recapitulation with the purpose of instructing the people of Israel.

\section{Tradition history in Psalm 78}

Tradition history (Traditionsgeschichte) is different from the history of transmission (Überlieferungsgeschichte) (see Nasuti, 1988:1-7). While the latter concerns the study of the history of oral and/or written traditions during the period of their transmission, the former applies almost completely to the final stage of the tradition. According to Barth and Steck (1978:77-80) tradition history is concerned with the traditional content of a text rather than with the history of a textual unit itself, that is, transmission history or redaction history.

When traditio-historical analysis is applied to lyrical poetry, it seeks to determine the course of development, the possible ritualistic settings, and the traditional materials incorporated in each such poem, since like other biblical literature, poetic pieces were rooted in the life of the people (Knight, 1992:637). In their songs the Israelites gave expression to their joy, their sufferings, their beliefs, and their hope in which the ritualistic settings and contexts were closely tied. At the same time, the traditio-historical analysis is also relevant for genre analysis, since with regard to poetic texts it is required for the investigation of the store of formal language commonly used in a genre to express particular thoughts and moods (Kaiser \& Kümel, 1967:23).

Thus, a study of tradition history in Psalm 78 might make a significant contribution to the understanding of the ritualistic settings and contexts of the psalm, since this psalm is generally regarded as the longest review and a profound interpretation of Israel's historical traditions in the Psalter (Clifford, 1981:124).

\subsection{Wisdom tradition in Psalm 78}

The so-called wisdom tradition ${ }^{4}$ can be found in the introduction part of Psalm 78. In verse 2 the recitation of Yahweh's deeds and the people's unfaithfulness is specifícally called a wisdom utterance with the words משידה and The wisdom movement was diffused throughout the whole ancient Near East. In Israel, however, wisdom motifs developed a distinctive Israelite accent, as evidenced in Proverbs and other wisdom passages in the Bible: The fear of Yahweh is the beginning of wisdom (Proverbs 9:10; Job 28:28; and Psalm 111:10). Likewise, the psalmist of Psalm 78 emphasizes the importance of true wisdom in the sense that the beginning of wisdom is faith - faith in Yahweh, the God who is known and worshipped in Israel (cf. Anderson, 1983:215-216).

The so-called Song of Moses in Deuteronomy 32:1-43 also seems an appropriate comparison with the wisdom tradition in Psalm 78, especially in its opening wisdomlike utterance as part of a historical review and warning. Like the general Deuteronomic picture of Moses as the authoritative speaker of the ancient traditions, the psalmist of Psalm 78 authoritatively restates the ancient traditions so that Israel will be able to choose for

4 For the definitions or descriptions of the motifs and themes of the following traditions, see Kim, 1999:69-83. 
Yahweh (cf. Clifford, 1981:130-131).

At the same time, the ערורה and verse 5 exhibit some interesting connections with the wisdom tradition. This verse establishes a link between the laws and commandments or, in broad terms, the ancient traditions in the Torah and the perpetuation of Israel's heritage. In this regard, the wisdom tradition in the introduction of the psalm teaches Israel to know Yahweh in two ways: viz. through the laws, and through the historical confession of the praiseworthy deeds of Yahweh (Burden, 1994: 190, cf. Tate, 1990:289).

According to the wisdom tradition in Psalm 78, thus, the purpose of the psalm is to edify the congregation by the speaker who can authoritatively restate the ancient traditions through the recollection of a shared history, so that the people may learn from the past how to live in the present.

\subsection{Covenant-Torah tradition in Psalm 78}

The so-called covenant-Torah tradition can be found in verses 10 and 37 of Psalm 78, although the word Torah does not occur in verse 37 . Verse 10, speaking of the Ephraimites, declares "they did not keep the covenant of God, and they refused to walk in his Torah" while verse 37, likewise referring to the Ephraimites, states "their heart was not steadfast with him, nor were they faithful in his covenant (cf. Day, 1986:8).

The transmission of the covenant-Torah tradition, according to Kraus (1989:126), originally ran parallel to the transmission of the history of salvation. Likewise, in this psalm Yahweh bestows his בעללי־אל (verse 7). The recalcitrance of the people over against the ברוות (verse 7), is apparent in their attitude towards the deeds of the covenant and God's saving acts (verses lOfi). In verse 10 , the character of the teaching and the admonition, indeed of the actual warning, is brought into the presentation of the history by way of the foundational system of the covenant and the Torah. The history of the encounter between Yahweh and his people becomes a reflection of the conduct with regard to the order of salvation of the and with regard to the order of dominion and obedience of the תורה.

From verse 37, it is certain that constancy and faithfulness in the not achieved by Israel. In spite of their failure, God's covenantal love reaches to the new beginning of Israel (verses 68-72). In Psalm 78, therefore, the covenant-Torah tradition is used to describe the contradiction between the infidelity of the people who refused to walk in Yahweh's Torah and the faithfulness of God who remembers his covenant forever.

\subsection{The guidance tradition in Psalm 78}

The so-called guidance tradition in Psalm 78 is one of the common elements that unite the Exodus and the wilderaess tradition (verse 14, cf. Noth 1981:58-59). The tradition employs the traditional term $\mathrm{nm}$ (verses 52-53) as well as reference to the cloud and fire (verse 14). Only here, in the guidance tradition, that is, in verses 12-16 and verses 52-53, the positive tradition of Yahweh's aid to the people is found. Between verses 14-15 and 5253 , the guidance through the desert is repeated twice in the following manner:

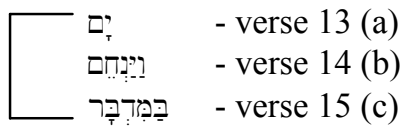

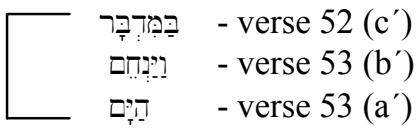

In Exodus 17:1-17 and Numbers 20:2-13, Moses strikes the rock for water in response to the murmuring of the people. Psalm 78 , however, makes the miracle one of pure grace. 
God's initiative, not the people's sin, provokes the outpouring. It has been cast into two parallel pictures: the splitting בבקע) of the sea and the splitting (בקע) of the rocks. Yahweh controls the sea that the Israelites cross (verse 13) and the rivers from which they drink (verse 16) for the benefit of his people (Clifford, 1981:132).

The metaphor of the people as a flock of sheep graphically depicts the nature of the people's dependence on Yahweh. It is also signifícant here in verse 53 that the miracle at the Red Sea is mentioned only after the motif of Yahweh's leadership in the wilderness has been developed (cf. Coats, 1968:205).

In the Asaphite psalms, according to Nasuti (1988:89), the term occurring in the Hif'il (verse 52) only appears with God as the subject (cf. Psalm 80:9). In other passages, such as Exodus 15:22, it is also found with Moses as the subject. However, with the omission of the name of Moses in the recitation, the guidance tradition in Psalm 78 stresses the community's dependence on God (see Burden, 1994:191).

\subsection{The wilderness tradition in Psalm 78}

In Psalm 78, the so-called wilderness tradition appears in the historical section contained in verses 17-41. This wilderness tradition itself is firmly associated with the so-called murmuring tradition, since the murmuring tradition is related to the complaints the Israelites made about the shortage of food and water while on their way from Egypt to the Promised Land, especially in the wilderness. According to Coats (1968:223-224), "the unit in verses 17-41 has its root in the murmuring tradition as it is known in the Pentateuch, but (it) reflect(s) a peculiar interpretation of this tradition." In Psalm 78 the murmuring is provoked by the people's need for food while there is abundant water. From this murmuring context, the so-called testing motif could also have come into Psalm 78. The motif of Israel testing God occurs three times in Psalm 78, viz. verses 18, 41 and 56. According to Campbell (1979:69), this in itself is remarkable because there are only six other occurrences in the Old Testament where נס is used of Israel testing Yahweh. ${ }^{5}$

In verses 21-30 the entire episode of the miraculous provision of food is conveyed under divine wrath. Here, the traditions that are separate in the Pentateuch are united, and function differently: the manna, the quails (in Psalm 78, flying birds), and the outpouring of divine wrath in the act of eating (cf. Clifford, 1981:133). Both the manna, which in the Pentateuch retains a positive nature (e.g., Exodus 16; cf. Numbers 6ff), and the quails are associated with the ungrateful attitude of the people in Psalm 78 (Burden, 1994:193).

The wilderness tradition in Psalm 78, thus, represents a fully developed, unbroken recitation of Israel's rebellious history. However, the simple distinction between a "positive" and a "negative" interpretation of the wilderness period can be dangerous (Davies, 1992:914). Even in the wilderness tradition in Psalm 78 Yahweh is repeatedly portrayed as providing for Israel's needs in the arid land in the most dramatic ways. Verse 32 illustrates the theme of God's guiding presence in the wilderness, that is, in spite of all this. The psalmist recalls that God provided water miraculously as a compassionate act. The proving statement in verses 20-21 calls upon the goodness of God's actions in the past. The fact that the question calls upon the goodness of God, intended to create a sympathetic response to their present needs, indicates that the water miracles represented the goodness of the wilderness experience (see Burden, 1994:192-193; also Coats, 1968:77-78). In spite of all that God had done for the people, they persistently failed to believe.

Therefore, the pivotal section of the wilderness tradition, according to Burden (1994:

5. These are Exodus 17:2,7; Numbers 14:22; Deuteronomy 6:16; and Psalms 95:9; 106:14 
191), is verses 38-39, which affirms the compassion (רחוּם) of God as the reason why God did not destroy Israel in the wilderness (see Nehemiah 9:17). Here especially, in verses 35, 39 and 42 the psalm stresses the importance of remembrance for the survival of the ancient traditions and the perseverance of faith in the community. In this respect, the wilderness tradition aids the remembrance of the rebellions of Israel. The community is encouraged to remember, and not to forget, the past as foundation for their new covenant loyalty (Burden, 1994:192, see also Greenstein, 1990:201).

\subsection{The Exodus tradition in Psalm 78}

In Psalm 78, verses 12-16 cconstitute the so-called Exodus tradition with a credo-like recitation of Yahweh's aid at the time of the entering of the wilderness period according to Coats (1968:200-201). Verse 12, especially, seems to be a summary of the Exodus tradition: In the sighi of their fathers he performed a wonder, in the land of Egypt, the field of Zoan. Here, in verses 12-16, the wondrous crossing of the Red Sea and the provision of abundant water are characterized by an emphasis on Yahweh's deeds rather than the people's response.

After the recitation of the history of Israel's rebellion in verses 17-41, verse 42 returns to the Exodus tradition, which is also characterized by the kind of recitation which concentrates on Yahweh's deeds. This unit continues without break through verses 54-55, which describe the entry into the Promised Land.

This long recitation of the Exodus tradition, especially, is represented by the plague narrative in verses 42-51, which constitutes a part of the people's departure from Egypt in the Exodus tradition. With the plague narrative, the Exodus tradition is freely varied and reduced to a few specific pictures (Kraus, 1989:129). Here the plagues are the central feature of the "signs" and "wonders" of Yahweh, which have not been remembered by the Israelites. Although the plague traditions are found in other passages of the Old Testament, the plague account in Psalm 78 is presented in a different form from that found elsewhere, that is, in Exodus 7-12 and Psalm 105:27-36. ${ }^{6}$

When the different aspects of the plague accounts in other passages of the Old Testament are considered, the plague tradition seems to be fluid and malleable enough to be fashioned in different ways for different contexts (Tate, 1990:293). The exact details of the plagues, however, are not a matter of great concern. Rather, what mattered most is the impact on the account. In these plague traditions, therefore, the weight is on Yahweh's praiseworthy deeds, both in the plagues directed against Egypt and in the deeds directed in favour of Israel. At the same time, it shows part of what the Israelites have not remembered.

\subsection{The conquest tradition in Psalm 78}

In Psalm 78, verses 54-55 seem to introduce the so-called conquest tradition since the Promised land is regarded as Yahweh's holy territory that is gained and given by the right hand of Yahweh. Here, similar to the guidance tradition, the tradition has no negative overtones.

In addition to this, verses 65-72 describe the intervention of Yahweh in a new battle for Israel, viz. his rejection of the tent of Joseph and the tribe of Ephraim, and his choice of a new shrine - Zion in the tribe of Judah - and a servant, David. The divine warrior wakes from his sleep, conquers the enemy, and then chooses a new shrine for his dwelling. God chooses (בחר) Zion and David, and rejects (מאס) Joseph and Ephraim, in language reminiscent of 1 Samuel

6. For a detailed comparison of different plague accounts, see Kim, 1999:78-79. 
15:26-28 and 16:1-13. There God rejects (מאס) Saul, a man of non-Judahite origins, and chooses (בחר (Clifford, 1981:136). The conquest tradition of Psalm 78 thus unites the old conquest traditions with the new tradition of the choice of Zion and David.

From an investigation of the tradition history Psalm 78 seems to stand in the major stream of Israel's historical traditions. ${ }^{7}$ Psalm 78 is a liturgical celebration of God's merciful choice of Zion and David as the continuation of the ancient shrine, celebrating the covenant-Torah tradition and the Exodus-conquest traditions. It retells the ancient traditions that were common to both the North and the South, so as to show that the divine abandonment of the old Northern shrine is not the end of God's love of the North. Zion in Judah is the successor to Shiloh, and is the divine dwelling for all the children of Israel (cf. Clifford, 1981:137, also 141). This celebration of the wisdom, covenant-Torah, guidance, wilderness, Exodus, and conquest traditions are united in Psalm 78 by forming a new tradition of Davidic Zion, since this psalm shows "how the different traditional elements were welded together and combined to make a new set of traditions" (Knight, 1977:121). Psalm 78, thus, eventually becomes to stand in the new welded tradition of praising the great "history-of-salvation deeds of Yahweh" (Kraus, 1989:125). From this new welded tradition, Psalm 78 stresses the importance of remembrance with regard to the survival of the ancient traditions, and of the perseverance of faith in the community (cf. Burden, 1994:191). In this regard, the tradition history of Psalm 78 also creates homiletic usage of the traditions where the traditions are exploited homiletically in a variety of ways (see Childs, 1992:131).

\section{Dating and historical setting (with the Sitz im Leben) of Psalm 78}

Any question of dating involves both the psalms as individual compositions and the Psalter as a whole. It is, however, hard to define the time of origin of the individual psalms and the various collections (see Rendtorff, 1985:249). For this reason, the time when the individual psalms came into being can be determined only by the careful exegesis of each one of them and then only in part and approximately (Weiser, 1961:279). In addition to this, comparative study of motifs and content against the background of the entire Old Testament can also often provide more clues for dating the Psalms (Fohrer, 1986:284).

A description of the historical setting (with the Sitz im Leben) of the Psalms is also difficult to provide because the book of the Psalms is obviously a collection rather than a unified composition and the individual psalms themselves are historically nonspecific (see Dillard \& Longman, 1994:212-214). The historical setting (with the Sitz im Leben) refers mainly to that sociological setting within the life functions of Israel (e.g., worship, education, entertainment, politics, and the law, etc.) in which particular rhetorical forms (legends, sayings, liturgical formulae, psalms, prophecies, and parables, etc.) first took shape (see Soulen, 1976:151; also Muddiman, 1990:240).

Reputable scholars of the last half-century differ widely among themselves on the dating and the historical setting (with the Sitz im Leben) of Psalm 78. It has been dated as early as the tenth century, within the period of the divided monarchy (922-587 B.C.), and as late as the post-exilic period. The text also raises other questions about the dating and historical setting of the psalm that cannot be answered conclusively (cf. Rogerson \& McKay, 1977:139-140). In this section, a comparative study of the scholarly opinions about the dating and the historical setting (with the Sitz im Leben) of Psalm 78 is needed in order to

7. For a discussion of the relationship between the traditions in Psalm 78 and other passages of the same traditions in the Old Testament, see Kim, 1999:80-82. 
attain a fresh insight into the dating and historical setting of the psalm.

\subsection{Early dating and historical setting}

The psalm is dated early by scholars to whom Psalm 78's triumphant ending with the reign of David indicates a date of composition during that period.

The earliest dating of Psalm 78 is that of Eissfeldt (1958:34-37), who dates the psalm to the early United Monarchy, because the division of the kingdom is not mentioned. For Eissfeldt (1958:36), the time of the writing of Psalm 78, thus, is probably the time of 930 B.C., and that suggests itself as the termius adquem for the psalm. Hengstenberg (1964:449479) and Hofbauer (1967:41-50) similarly attribute the psalm to Asaph in the time of David according to the heading of the psalm itself.

For Freedman (1976:55-107), the use of divine names and titles in a psalm is the most important indication for dating the psalm. He puts Psalm 78 into the group of the so-called monarchic syncretism (tenth century or later). In this period, according to Freedman (1976:57), a new set of titles and epithets appears, reflecting the syncretistic tendencies of the religion of the monarchy.

Among the opinions of early dating, Campbell's opinion seems to present a competent argument. Campbell relates Psalm 78 to the so-called Ark narrative which recounts the fate of the Ark in 1 Samuel 4:1-7:1; 2 Samuel 6 and 7. The latter sections (verses 59-72) of Psalm 78, according to Campbell (1975:215), are closely paralleled to the Ark narrative. Thus, for Campbell the concern of Psalm 78 is a tenth century concern to understand and interpret theologically the events from Shiloh to Jerusalem. The fact that this same history appears to be represented in the Ark narrative, most probably prior to the Solomonic temple, reinforces the tenth century dating (Campbell, 1979:76).

As far as this tenth century dating is concerned, the historical setting of Psalm 78 is the tenth century Jerusalem where the psalm might have originated. The evaluation of the election of David suggests a court setting, and yet his kingship is given no direct emphasis (verses 71-72). This psalm interprets the loss of the Ark from Shiloh as signifying Yahweh's rejection of the Israel of old, and it interprets the success of David as signifying a resumed but new relationship of Yahweh with Israel. It is stimulated by David's establishment of kingship in Jerusalem (cf. Campbell, 1979:76).

Concerning the Sitz im Leben of Psalm 78 based on this early dating, the introduction and the final verse point towards the circles of the wise, perhaps among the counselors or theologians of the king. The opening address, "O my people," might indicate that it was written in these circles for the temple or the court recital by a representative of the king (cf. Campbell, 1979:77).

As far as the historical component of Psalm 78 is concerned, however, Campbell's argument seems to be incorrect. Campbell believes the psalm to have been written to legitimate the newly united kingdom, but many of the phrases of this psalm would be offensive to the Northern part of this kingdom since tribal loyalties were strong in that period (cf. Tate, 1990:286).

Clifford (1981:138) similarly states that "the intention of the psalm is to situate it in a time of division between the North and the South." According to him, Eissfeldt's and other scholars' dating of the psalm to the time before the Northern secession under Jeroboam in the late tenth century makes overly specific the deliberately generalized introduction, especially verse 9. Moreover, Clifford (1981:136) objects to Campbell's relating Psalm 78 to the so-called Ark narrative because the divine dwelling in the psalm is regarded as the old tent (verse 60), and not the "temple" of the folkloristic narratives of I Samuel 1-3. 


\subsection{Late dating and historical setting}

At the opposite end of the spectrum, there is another opinion of dating Psalm 78, that is, those who support a very late post-exilic dating.

Gunkel dates Psalm 78 to the post-exilic period because of a combination of different genres, which according to him, points to a late date. For Gunkel, thus, this psalm allegedly depends on the already formulated Old Testament historical books (Gunkel, 1926:342).

Kraus also maintains a post-exilic date for the psalm, although he is open to a pre-exilic composition date. For Kraus (1989:123-124), the incorporation of the David-Zion tradition in Psalm 78, which is canonically circumscribed and concluded with the distribution of the land, could best be explained on the basis of the interests and contrasts of the postexilic time. In this regard, Kraus designates a cultic festival as the Sitz im Leben for the didactic treatise of the history in Psalm 78, even though he cannot specify the festival and the aspect of the cult he refers to. For Kraus (1989:213), thus, it is sufficient for the Sitz im Leben of this psalm that the singer, very likely a (Levitical) priest, turns to the community like a teacher of wisdom and addresses it with "my people" in the manner in which the wisdom teacher addresses his student with "my son".

Clifford (1981:138) opposes this interpretation by arguing that "a post-exilic date (as) suggested by Gunkel for stylistic reasons, and by other scholars for historical reasons, seems excluded by the lively role of the Davidic shepherd as the unifying agent in verses 70-72." Moreover, by itself, the lack of post-exilic terms in Psalm 78, such as "remnant", "refugee" and "return" or post-exilic concerns, such as the practice of inter-marriage and the loss of Jewish sovereignty (see Nehemiah 9:36-37), might disturb a very late dating for this historical psalm.

Stern (1996:42) also opposes Kraus's viewpoint that "the incorporation of the DavidZion tradition into the sacred history of Israel began earlier than Chronicles, as the present book of Samuel attests." It probably began with David and was reinforced by David's descendants, who had an interest in such incorporation. Furthermore, for Stern (1996:44-45), a post-exilic dating of Psalm 78 seems to be inaccurate because there is no trace of the fall of Judah, which would surely have influenced the psalm's interpretation of history in an obvious way.

\subsection{Divided monarchy dating and historical setting}

Many scholars seem intuitively attracted to the proposition that the period of the divided monarchy (922-587 B.C.) is the right time to place Psalm 78.

Junker (1953:493-494) argues for an Hezekian provenance for this psalm. Having admitted to the Deuteronomic influence, Junker (1953:498) sees the wisdom strain in the psalm as related to the wisdom activities of the scribes of Hezekiah's court, mentioned in the book of Proverbs. Carroll (1971:146-147) also relates the starting of the Deuteronomic process in Psalm 78 to the eighth century because, for him, Deuteronomic process may have started in Northern Israel in the eight century and moved the South to Judah after the collapse of Samaria.

Dahood (1968:238-239) broadly establishes the chronological limits of the language of Psalm 78. According to him, the historical reference in Psalm 78 points to the composition of the psalm between 922-721 B.C. and linguistic evidence corroborates this inference since the frequent use of yqtl in Psalm 78 is the normal form of expressing past events in Ugaritic poetry and, to a lesser extent, in early biblical poems. Arguing from linguistic evidence, Robertson (1972:151) also dates Psalm 78 in the period of the divided 
monarchy, because the forms of standard poetic Hebrew are overwhelmingly predominant in it.

Stern (1996:48-49) also argues in favour of an eighth century dating. He regards an indication in Psalm 78 of contact with Hosea and Amos as powerful evidence that this psalm could not have been written prior to the eighth century. He believes that the unique expression, "like a deceitful bow" in verse 57 of Psalm 78 is taken directly from Hosea 7:16. Likewise, a short, vague account of obscure battle, ending with the word, "on the day of battle" (verse 9) seemingly owes something to Hosea 10:14. Furthermore, Psalm 78:15 is matched to Amos 7:4, and Psalm 78:67 to Amos 5:6, 5:15, and 6:6 (Stern, 1996:50-51). Stern, thus, convincingly asserts that "the confluence of verses from Psalm 78 with these two prophets and many other eighth century sources indicates that the psalmist was contemporary with the eighth century" (Stern, 1996:51).

Clifford also insists that the date of Psalm 78 must be during the period of the Hezekian reform or the Josianic reform. According to him, the Deuteronomic language and the concern of the psalm to unite all Israel under the Davidic monarchy in a single place of worship suggests a time during the Hezekian reform of the late eighth century or the Josianic reform of the late seventh century since both reforms invited the Northern tribes to return to unity under David with worship in Jerusalem (Clifford, 1981:138).

As far as the historical setting is concerned, for Clifford, the Hezekian reform is a more likely situation for Psalm 78 since the successive military defeats of Ephraim in 734732 B.C. and the destruction of Samaria, the capital city, in 722 B.C., well illustrate the Ephraimites' turning back on the day of battle of verse 9, the proof of Yahweh's abandonment of the shrine. The liturgy combines into one divine action the rejection of Shiloh and later Northern shrines. The instability of the kings from Zechariah in 746 B.C. to Hosea in 722 B.C. makes the eternal promise to the Davidic shepherd in verses 70-72 more attractive. The Northern victims of the Assyrian destruction in 722 B.C. are told their shrine has been superseded by Jerusalem where a fresh beginning could take place. The Israelites should not be like their forefathers who trusted in a divinely rejected shrine. 2 Chronicles 30:1-27 describes the Hezekian reform to unite all Israel around one sanctuary after the destruction of Samaria in 722 B.C. ${ }^{8}$ (see Clifford, 1981: 138-139).

The investigation of Psalm 78's Sitz im Leben is as controversial as its date. However, the instructional nature of Psalm 78 should not lead one to deny the cult for its Sitz im Leben (Nasuti, 1988:156). It is certain that the psalmist addresses a group in verses 1-5, and, then, there is good reason to assume that the psalm was intended for use in public worship (Tate, 1990:286-287). Such communal indications in verses 1-5, viz. the address to the people in the opening verse ( $O$ my people) and the first person plural in verses 3-5, accord well with the specifically communal setting of Deuteronomy 32 and the cultic and communal setting of Psalms 105 and 106 as seen in 1 Chronicles 16 (Nasuti, 1988:156). Concerning the speaker of Psalm 78 in public worship, this psalm can be seen as an example of Levitical preaching (cf. Kraus 1989: 123). Even more such a Levitical actualization would fit with the Levitical performers of its closest parallels, the Moses of Deuteronomy 32 and Asaphites of 1 Chronicles 16. Then, it should be noted that these parallels are seen as songs. Thus, one should perhaps not distinguish too finely between Levitical preaching and Levitical song, since both may be actualized by the same personnel and even have the same purpose (cf. Nasuti, 1988:156).

In conclusion, although it is quite impossible to be certain about the date or original

8. For a detailed discussion of Hezekiah's reform, see Bright, 1981:280-282. 
setting of this psalm, the period of the divided monarchy (922-587 B.C.) for its dating and historical setting seems to be better attested than a late or early dating. The historical component of Psalm 78 sustains this kind of assumption. On the one hand it is quite difficult to accept an early dating of this psalm to the period of the united monarchy for many of the phrases of this psalm would be offensive to the northern part of the newly united kingdom. The fact that the psalm ends with David does not necessarily mean that the author had reached a contemporary period. This sudden ending seems to be not for a historical reason, but for a theological reason. On the other hand, the lack of any intimation as to the disasters that befell Judah and the lack of post-exilic terms discourage a post-exilic late dating for this historical psalm. Moreover, there is no doubt from the psalm that the Temple in Jerusalem still stands. The combination of wisdom and Deuteronomic language in the psalm is also an indication of its pre-exilic origins, rather than the opposite. The comparative study of motifs, linguistic evidence and content of Psalm 78 against the entire Old Testament also sustains the divided monarchy dating and historical setting. Therefore, the psalm is dated in the time of the divided monarchy, and probably later rather than earlier in that period. More precisely, the concern of the psalm to unite all Israel under the Davidic monarchy in a single place of worship would suggest a time during the Hezekian reform of the late eighth century.

\section{Canonical shape of Psalm 78}

Recently growing interest has emerged among scholars attempting to understand the book of Psalms not only as a collection of individual psalms but also as a coherent literary work and canonical whole (see Howard, 1999:329-368). Increasingly scholars are discerning evidence of editorial activity within the Psalter. The purposeful arrangement of psalms within the collection seems to have given the final form of the whole Psalter a function and message. This new interest in editorial activity is clearly related to the current trend in biblical studies toward unitary, literary, and canonical readings of the Bible (see Howard, 1993:52). In his discussion of editorial activity in the Psalter, Howard (1993:68) distinguishes between the higher level of collections and large, organizing principles over the fmal form of the Psalter and the lower level of interest in relationships between adjacent psalms. The work at the higher level is valuable in setting the framework within which more detailed work can proceed while at the lower level, the work functions to provide more specific evidence and to confirm or modify the higher-level investigation.

In this regard, progress in the investigation of the purposeful arrangement of the psalms can be achieved as follows: 1) the recognition of clear indications of psalm groupings where discernible; 2) the detailed and systematic investigation of linguistic and thematic connections between psalms within these groupings and their subgroups; and 3) to make suggestions as to the appropriate social/historical matrix (cf. Wilson 1993:50-51). This kind of approach, however, carries its own danger of contextual interpretations becoming arbitrary. Murphy (1993:21-28) and Brueggemann (1993:30) stress the need for caution. Therefore, being cautious of such arbitrary contextual interpretations, the canonical shape of Psalm 78 both in the Psalter as a whole, and in the adjacent Psalms, viz. Psalms 77 and 79 will now be discussed.

\subsection{Canonical shape of Psalm 78 in Book III of the psalter}

The beginning of Book III of the Psalter with Psalm 73 appears to be, and is usually interpreted as, a personal expression of someone who is in trouble but who is able at the same time to maintain hope. It is clear for McCann (1993:95-96) that this initial psalm of Book III is 
linked to the subsequent psalms by the device of repetition. After careful examination of the final form of Book III, McCann (1993:98) asserts that the psalms in Book III celebrate God as judge over all the earth and all the nations (see Psalms 75, 76, 81:12-17 and 82). At the same time, the psalms rehearse the praiseworthy deeds that God had performed in the past despite Israel's faithlessness (see Psalms 77:12-21, 78 and 81). The two rehearsals of Davidic/Zion theology (Psalms 78:67-72, 89:1-38) and the two songs of Zion (Psalms 84 and 87) might be called two-edged expressions of hope. On the one hand, they serve to remind the community of God's past deeds on behalf of the people; on the other hand, the juxtaposition of traditional Davidic/Zion theology with laments of the community makes the traditional hope ring hollow at best. ${ }^{9}$

An analysis of the canonical structure of this Book III of the Psalter by Cole (1996: 756838) also demonstrates a consistent dialogue from start to finish, springing from the promise to David's sons of Psalm 72 at the end of Book II. The individual speaking in the first psalm, Psalm 73 of Book III, laments that conditions are opposite to those predicted in Psalm 72. He and his nation continually ask "how long" (or "why") before the present desolation ends (Psalms 74:1,9-10, 77:8-10, 79:5,10, 80:5,13, 85:6 and 89: 47). In one of various divine responses (Psalm 82:2), the same question is put to the nation's authorities about their partiality in judgment. To the questions of "how long" in Psalm 77:8-10, the response in Psalm 78 ironically details the continual rebellion of the nation, utilizing vocabulary from the previous queries themselves. The divine answers in Psalms 75-76 assure eventual justice and peace, but without a timetable. The Davidic individual portrayed in Book III, especially in Psalms 84-89, is the embodiment of righteousness and truth promised in the eschatological kingdom. To the fmal question of "how long" in Psalm 89:47, the following Psalm (90) of Book IV responds that divine and human perspectives on time differ.

Thus, as far as the canonical shape of Psalm 78 in Book III of the Psalter is concerned, it becomes evident that Psalm 78 turns out to be a divine answer to the question of "how long" shared with various psalms of Book III. The words of Asaph

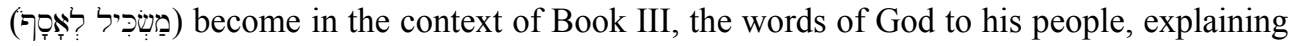

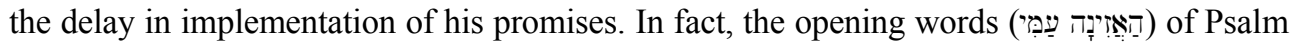
78 are perfectly consistent with this interpretation (cf. Cole, 1996:8). In this regard, given the strong disjuncture caused by disparate headings and the doxology of Psalm 72:18-20, the grand promises of Psalm 72 serve as a basis for the dialogue between God and his people, including Psalm 78.

\subsection{Canonical shape of Psalm 78 among adjacent Psalms}

Psalms 77 and 78 are categorized as the so-called "twin psalms" (Zwillingspsalmen) by Zimmerli (1972:105-113). Psalm 77:21, especially, has numerous contacts with Psalm 78, being an appropriate preparation or link to it (Cole, 1996:225). The verb נחה $77: 21^{10}$ is a major theme of Psalm 78 (verses 14, 53 and 72) as is the metaphor of Israel as a flock ( (א, Psalm 78:52,70). While in Psalm 77:21, Israel appears as a flock that is led by Moses and Aaron, in Psalm 78:72 they appear as a flock that is led by David (Keil \& Delitzsch, 1975:361).

The situation in Psalm 79, however, seems to be the opposite from the presentation of

9. For a detailed examination of the final form of Book III of the Psalter, see Kim, 1999:19-24; also McCann, 1993:95-100.

10. For the verse indication of Psalm 77, the Masoretic text is one number more than major English translations. In this study the verse indication of the Masoretic text for Psalm 77 is adopted. 
David as the picture of a future liberator of the nation in Psalm 78 (cf. Cole, 1996:335). Because while the penultimate verse 71 of Psalm 78 describes how David was brought (הביאו) to shepherd the inheritance (נחלתו), immediately following in Psalm 79:1, the gentile nations invading (באו) that same inheritance (בנחלתו) presents the opposite of the previous promise. Israel is designated by the word pair עם / עחלה in Psalm 78:71, which is divided up across Psalm 79 as a device of inclusio in verses 1 (נחלה) and 13 (עם). In fact, the promise to recount God's praise in Psalm 79:13 makes clear that this confessing nation identifies with David's flock and not the disobedient nation in Psalm 78. In this regard, the guidance by Moses and Aaron announced in Psalm 77:21 and then detailed in Psalm 78 was obviously not effective in producing a faithful flock. David could take over this flock (78:70) or nation (78:71) finally when God arose to deliver his people. His hands (כיפיו, 78:72) replace those of Moses and Aaron (ביד, Psalm 77:21), all of which were only instruments of the divine hand (דו יו Psalm 78:42).

For one of the significant words in Psalm 78, זכר, some obvious parallels can also be found among adjacent Psalms (see Cole, 1996:218). In Psalm 77:4 a series of the root is initiated (verses 4, 7 and 12 - twice) where the psalmist of Psalm 78 remembers God's past mercy (verses 8-10) and miracles (verses 12-13). Their memory, however, turned out to be only temporary, for in Psalm 78:42 they forgot (לאזיזרו) his mighty works in Egypt, and in Psalm 79:8 they want him to forget their sins. This request in Psalm 79:8 asks that their sins (עונת) be forgotten, an appeal based on the words of Psalm 78:38 that God covers iniquity (כפר עון). Likewise the psalmist in Psalm 77:10 ironically wonders if God has forgotten (השכח), but eventually they forgot the work of his mighty hand in redemption (לאיזכרו, Psalm 78:42). All the while God himself was remembering them and their frailty (יזכר, Psalm 78:39). In this regard, the verb כפר in Psalm 78:38 is repeated in the same series of requests for forgiveness of Psalm 79 (verse 9, וכפר) in imperative form. A further parallel between these two series of verses is found in the description of God as merciful in Psalm 78:38 (רחום), and the request that he demonstrate his mercies (רחמיך) in Psalm 79:8. Consequently, a repeated appeal is made to Psalm 78 where God's merciful character is affirmed in the midst of rebellion (Cole, 1996:338).

In addition to this, the obedience of the psalmist in Psalm 77 parallels the commands and actions of the speaker in Psalm 78:1-8. Consequently, a single pious Davidite begins to emerge from Book III who stands out from a disobedient nation (cf. Cole, 1996:219). In the same way, the people of Psalm 79 identify themselves with the faithful ones of Psalm 78:3-4, a community that passes on (מספרים , ספרו) the praises (נהלות) of Yahweh (cf. Psalm 79:13, נספר תהלתך).

Therefore, as analyzed above, Psalm 78 can be regarded as an example of a response from God to the questions and complaints of Psalms 77 and 79 and the divine answer to the question of "how long" in various psalms of Book III of the Psalter. In other words, Psalm 78 presents the divine answer to the complaints of Psalm 77 and also reveals that the individual of Psalm 77 stands out from the nation as faithful and obedient. In this regard, the people of Psalm 79 also declare their faithfulness as opposed to those of Psalm 78. To this Psalm 78:38 responds that God is still merciful and prone to delay his wrath. These answers of Psalm 78 do mean that both the people in Psalms 78 and 79 and individual in Psalm 77 should have hope and have confidence only in God. To the fmal question of "how long" in Book III, the faithfulness of Yahweh in Psalm 89 contrasts sharply with the unfaithfulness of Israel in Psalm 78 with describing God's faithfulness to the covenant made with David. 


\section{Conclusion}

In conclusion, it becomes quite clear that each and all of the exegetical aspects of the authorial dimension of Psalm 78 have brought new and helpful insights. The study of the psalm's heading not only helps to understand its Sitz im Leben but also makes some contribution to understand its genre. The discussion of the date and historical setting of the psalm expedites the understanding of the psalm's own Sitz im Leben, that is, the recitation of the psalm in the Jerusalem temple by a (Levitical) priest, when there was an attempt to unite the worship of the North and the South during the divided monarchy (922-587 B.C.), more precisely the Hezekian reform of the late eighth century. The traditio-historical analysis helps to understand the message of the psalm. The traditions of wisdom, covenantTorah, guidance, wilderness, Exodus, and conquest are united in Psalm 78, forming a new welded tradition which stresses the importance of remembrance with regard to the survival of the ancient traditions. The investigation of the canonical context of the psalm also gives some helpful insight in how the message of Psalm 78 fits in with the message of the adjacent psalms, and also with the overall message of Book III of the Psalter. Psalm 78 can be seen as an example of God's response to the questions and complaints from the adjacent psalms and other psalms in Book III of the Psalter. In this regard, Psalm 78 is not a mere report of Israel's failure, but of the triumph of Yahweh's covenantal faithfulness that creates a new beginning for the people of God. ${ }^{11}$

\section{BIBLIOGRAPHY}

Anderson, AA 1972. Psalms: The New Century Bible Commentary. Vol. 1. Grand Rapids: Eerdmans.

Anderson, BW 1983. Out of the depths: the Psalms speak for us today. Philadelphia: Westminster Press.

Archer, GL 1994. A survey of Old Testament introduction. Chicago: The Moody Bible Institute.

Barth, H and Steck, OH 1978. Exegese des Alten Testaments: Leitfaden der Methodik.

Neukirchen-Vluyn: Neukirchener Verlag.

Bright, J 1981. A history of lsrael. 3rd ed. Philadelphia : Westminster Press. Brueggemann, W 1993. Response to James L Mays, "The question of context" in McCann, JC, (ed.). The shape and shaping of the Psalter. Sheffield: JSOT Press. p.29-41.

Burden, TL 1994. The kerygma of the wilderness traditions in the Hebrew Bible. New York: Peter Lang.

Buss, MJ 1963. The Psalms of Asaph and Korah. Journal of biblical literature, 82:382-392.

Campbell, AF 1975. The Ark narrative: a form-critical and traditio-historical study. Missoula: Scholars' Press.

Campbell, AF 1979. A contribution to the theology of tenth century Israel. Catholic Biblical Quarterly, 41:51-79.

Carroll, RP 1971. Psalm LXXVIII: vestiges of a tribal polemic. Vetus Testamentum, 21: 133150.

Childs, BS 1971. Psalm titles and Midrashic exegesis. Journal of Semitic studies, 16(2): 137150, Autumn.

11. The final article in this series will discuss the dimension of the reader/exegete in the reading of Psalm 78. 
Childs, BS 1979. Introduction to the Old Testament. Philadelphia: Fortress.

Childs, BS 1992. Biblical theology of the Old and New Testaments. Minneapolis: Fortress.

Clifford, RJ 1981. In Zion and David a new beginning: an interpretation of Psalm 78. In

Halpern, B, Levenson, JD \& Cross, FM, (eds.). Traditions in transformation. Winona Lake: Eisenbrauns. p.121-141.

Coats, GW 1968. Rebellion in the wilderness. Nashville: Abingdon Press.

Cole, RL 1996. Rhetorics and canonical structure in the Hebrew Psalter Book III (Psalms 73-89). Los Angeles: University of California. (Thesis - DPhil.)

Craigie, PC 1983. Psalms 1-50. Waco Texas: Word Books.

Dahood, MJ 1968. Psalms II: 50-100. New York: Doubleday.

Davies, GI 1992. Wilderness wanderings. In Freedman, DN, (ed.) The Anchor Bible Dictionary. Vol. 6. New York: Doubleday. p.912-914.

Day, J 1986. Pre-Deuteronomic allusions to the covenant in Hosea and Psalm LXXVIII. Vetus Testamentium, 36:1-12.

Dillard, RB \& Longman, T 1994. An introduction to the Old Testament. Grand Rapids: Zondervan.

Eissfeldt, O 1958. Das Lied Moses Deuteronomium 32:1-43 und das Lehrgedicht Asaphs Psalm 78 samt einer Analyse der Umgebung des Mose-Liedes. Berlin: Akademie.

Erickson, MJ 1993. Evangelical interpretation. Grand Rapids: Baker.

Fohrer, G 1986. Introduction to the Old Testament. London: SPCK.

Freedman, DN 1976. Divine names and titles in early Hebrew poetry. (Cross, FM, Lemke, WE \& Miller, PD, (eds.). Magnalia Dei: the mighty acts of God. Garden City: Doubleday. p.55-107.

Greenstein, EL 1990. Mixing memory and design: reading Psalm 78. Proof texts: A Journal of Jewish Literary History, 10:197-218.

Gunkel, H 1926. Die Psalmen. Göttingen: Vandenhoeck and Ruprecht.

Harrison, RK 1969. Introduction to the Old Testament. London: Tyndale.

Hengstenberg, EW 1964. Commentary on the Psalms. Vol. 2. Edinburgh: T\&T Clark.

Hill, AE \& Walton, JH 1991. A survey of the Old Testament. Grand Rapids: Zondervan.

Hofbauer, J 1967. Psalm 77/78: ein “politisch Lied.” Zeitschrift fiir katholische Theologie, 89:41-50.

Howard, DM 1993. Editorial activity in the Psalter. In McCann, JC, (ed.) The shape and shaping of the Psalter. Sheffield: JSOTPress. p.52-70.)

Howard, DM 1999. Recent trends in Psalms study. In Baker, DW \& Arnold, BT, (eds.). The face of Old Testament studies: a survey of contemporary approaches. Grand Rapids: Baker Books. p.329-368.

Jonker, LC 1996. Plotting the exegetical-hermeneutical landscape. Scriptura, 59:397-411.

Jonker, LC 1998. Reading Jonah multidimensionally. Scriptura, 64:1-15.

Junker, H 1953. Die Entstehungszeit des Ps. 78 und des Deuteronomiums. Biblica, 34:487500.

Kaiser, O 1975. Introduction to the Old Testament. Oxford: Basil Blackwell.

Kaiser, O \& Kiimmel, WG 1967. Exegetical method: a student's handbook. NewYork: The Seabury Press.

Keil, CF \& Delitzsch, F 1975. Commentary on ihe Old Testament. Vol. 5. Psalms. Grand Rapids: Eerdmans.

Kidner, D 1973. Psalms 1-72. Leicester: Inter Varsity Press.

Kim, Y 1999. Reading Psalm 78 multidimensionally. Potchefstroom: Potchefstroom 
University for Christian Higher Education. (Dissertation - ThM.)

Kim, Y \& Van Rooy, HF 2000. Reading Psalm 78 multidimensionally: the textual dimension. Scriptura, 74:285-298.

Knight, DA1977. Revelation through tradition. In Knight, DA, (ed.). Tradition and theology in ihe Old Testament. London : SPCK. p. 143-180.)

Knight, DA 1992. Tradition history. In: Freedman, DN, (ed.). The Anchor Bible Dictionary. Vol. 6. New York: Doubleday. p.633-638.)

Kraus, HJ 1988. Psalms 1-59: a commentary. Minneapolis: Augsburg.

Kraus, HJ 1989. Psalms 60-150: a commentary. Minneapolis: Augsburg.

Lategan, BC 1992. Hermeneutics. In Freedman, DN, (ed.). The Anchor Bible dictionary. Vol. 3. NewYork: Doubleday. p. 149-154.)

Leupold, HC 1959. Exposition of the Psalms. Welwyn: Evangelical Press.

McCann, JC 1993. Books I-III and the editorial purpose of the Hebrew Psalter. In McCann, JC, (ed.) The shape and shaping of the Psalter. Sheffield: JSOT Press. p.93-107.

Mowinckel, S 1992. The Psalms in lsrael's Worship. Vol. 2. Oxford: Basil Blackwell.

Muddiman, J 1990. Form criticism. In Coggins, RJ \& Houlden, JL, (eds.). A Dictionary of Biblical Interpretation. London: SCMPress. p.240-243.

Murphy, RE 1993. Reflections on contextual interpretation of the Psalms. In McCann, JC (ed.). The shape and shaping of the Psalter. Sheffield: JSOT Press. p.21-28.

Nasuti, HP 1988. Tradition history and the Psalms of Asaph. Atlanta: Scholars Press.

Noth, M1981. A history of Pentateuchal traditions. Chico: Scholars Press.

Rendtorff, R 1985. The Old Testament: an introduction. London: SCM.

Robertson, DA 1972. Linguistic evidence in dating early Hebrew poetry. Missoula: Scholars' Press.

Rogerson, JW \& McKay, JW 1977. Psalms 51-100. Cambridge: Cambridge University Press. Schmidt, WH 1984. Old Testament introduction. New York: Crossroad.

Solomovic, E 1979. Toward an understanding of the formation of historical titles in the bookof Psalms. Zeitschrift für die Alttestamentliche Wissenschaft, 91:350-380.

Soulen, RN 1976. Handbook of biblical criticism. Atlanta: John Knox Press.

Stern, P 1996. The eighth century dating of Psalm 78 re-argued. Hebrew Union College Annual, 66:41-65.

Tate, ME 1984. The interpretation of the Psalms. Review \& Expositor, 81:363-375.

Tate, ME 1990. Psalm 51-100. Dallas: Word Books.

Weiser, A 1961. Introduction to the Old Testament. London: Darton, Longman \& Todd.

Weiser, A 1962. The Psalms. Philadelphia: Westminster Press.

Wilson, GH 1993. Understanding the purposeful arrangement of Psalms in the Psalter: Pitfalls and promise. In McCann, JC, (ed.). The shape and shaping of the Psalter. Sheffield : JSOT Press. p.42-51.

Zimmerli, W 1972. Zwillingspsalmen. In Schreiner J, (ed.). Wort, Lied, und Gottesspruch. Beitrage zu Psalmen und Propheten. Würzburg: Echter. p. 105-113.) 